\title{
HOUSING PRICE BUBBLE ANALYSIS - CASE OF THE CZECH REPUBLIC
}

\author{
Jan Čadil*
}

\begin{abstract}
The paper deals with the hypothesis of housing price bubble in the Czech economy. This topic is very popular among economists worldwide now, especially because of the U.S. housing crisis and subsequent collapses on financial markets. However, surprisingly there are not many analyses dealing with the Czech housing market (besides e.g. very brief Financial Stability Report published by the Czech National Bank in 2008) and with the possible housing bubble burst. The first standard bubble indicators like $\mathrm{P} / \mathrm{I}$ ratio are used to identify the bubble possibility on the Czech housing market. As the second step a regression analysis (VAR model) is being used for deeper analysis of the situation. The whole analysis is complicated by a lack of relevant data and quite short-time series.
\end{abstract}

Keywords: housing price bubble, housing market, $\mathrm{P} / \mathrm{l}$ ratio, speculation demand, market forward buying

JEL Classification: C22, D12, D84, L85, R21, R31

\section{Introduction}

Housing bubble and housing market crisis are very popular topics among economists now. Of course, such an interest is mainly caused by a situation in U.S. economy, where real estate crisis started and resulted in severe economical problems, but on the other hand, also other European economies faced rapid fall in real estate prices recently (the Great Britain, Ireland or Spain).Therefore, the question arises whether such a situation can take place in other economies like the Czech Republic.

Lots of analyses and papers were written concerning the housing crisis phenomena. Some economists were pointing at extremely fast and most likely speculative increase in housing prices before the U.S. crisis started. ${ }^{1}$ Their conclusions were usually quite cautious, admitting possible regional pattern of housing bubble or asynchronous development of bubbles. In addition, even politicians and well-known economists were not considering high housing prices and their acceleration as a possible threat for a long time. ${ }^{2}$ Real estate agents even considered rapid growth as sustainable and were recommending investing in this sector (Lereah, 2005, 2006). The more surprising was the housing market develop-

* Unicorn College; University of Economics, Prague a.s., Praha; Société Genérale, Paris

1 See Case, K. E., Schiller, R. J. (2003) and the paper discussion - Mayer, Ch., Quigley, J. M. (2003) or Noord, P. (2006). On the contrary, some institutions were denying the risk of housing bubble - see Harvard University, Joint Center for Housing Studies 2006 for example.

2 For example Alan Greenspan admitted he realized the housing bubble threat quite late - in the beginning of 2006 (Reuters, 2007) and he started to discuss the problem in public in 2007 (Financial Times, 2007). 
ment in late 2006 and 2007 when the bubble burst. The subprime mortgages then worsen the whole situation and transferred the bubble bust on the financial markets. ${ }^{3}$

It is usually being proclaimed that a share of risky mortgages in the Czech Republic is very low and therefore the Czech Republic cannot face the housing crisis like the USA or the Great Britain. However, it is only partially true. It is important to remember that it was speculative demand itself, which started the price bubble and housing crisis. Subprime mortgages only deepened the crisis and substantially harmed the financial sector. Speculations on the Czech housing market may exist, no matter whether domestic financial market is in a good condition or not. The possible bubble bust of course will not cause such disaster on domestic financial institutions (like in the case of subprimes) but economic threat is still quite high. Presumably the bubble bust would result in a loss of consumer confidence and negative wealth effect resulting in consumption decrease. Part of households will face the same problem as in the USA - the mortgage debt will suddenly overshoot the value of their houses and their wealth will substantially decrease.

The purpose of this paper is to analyse and to identify the housing price bubble and speculative demand in the Czech Republic.

\section{Data}

The analysis is mainly based on data taken from national database (CZSO) and the Czech National Bank. However housing prices data are unfortunately not perfectly relevant and reliable especially because time series available are considerably short. ${ }^{4}$ This fact slightly decreases the explanatory power of this study. Detailed data description is undertaken in the following sections of this paper.

\section{Housing Price Bubble - Identification}

It is generally quite difficult to identify price bubble on a particular market. There are several factors that may result in housing price acceleration without necessity to have a price bubble on the market ${ }^{5}$. The situation in the Czech Republic is even trickier because the housing market is partially under regulation and vital data are not available for longer-time period. Generally, the price bubble on any market can be defined as (Stiglitz, 1990 and Case, Schiller, 2003):

"If the reason that the price is high today is only because investors believe that the selling price is high tomorrow - when "fundamental" factors do not seem to justify such a price - then the bubble exists. "

In other words it is speculation that is behind the buyer's behaviour and speculation is the only true origin of any price bubble. Expectation of price acceleration of particular asset is resulting in higher demand and such increase in demand is pushing prices up. It is a self- reinforcing mechanism which is working until bubble bursts.

3 Levy Economic Institute is drawing attention to this danger in beginning of 2006.

4 The time series are available quarterly from 1998-2006. The Financial Stability Report (CNB, 2008) is referring to this problem of lack of data as well.

5 Typically low interest rate or strong population volume. 
On a housing market households or investors typically purchase real estates, which they would otherwise consider to be too expensive, because they believe that they will be compensated with rapid price increase in future (Case, Schiller, 2003). In such situation, the housing real prices grow fast and the share of price on income (P/I ratio) and on rents (P/R ratio) is going up. For example between 1995 and 2004 the $\mathrm{P} / \mathrm{I}$ ratio and $\mathrm{P} / \mathrm{R}$ ratio in 100 US selected metropolitan areas increased by $40 \%$ in average (Himmelberg, Mayer, Sinai, 2005).

Figure 1 and 2 shows the situation in the Czech Republic. $B$ stands for flats, $D$ for houses and $P$ for parcels. ${ }^{6}$

\section{Figure 1}

Price to Income (P/I) Ratio between 1998 and 2006
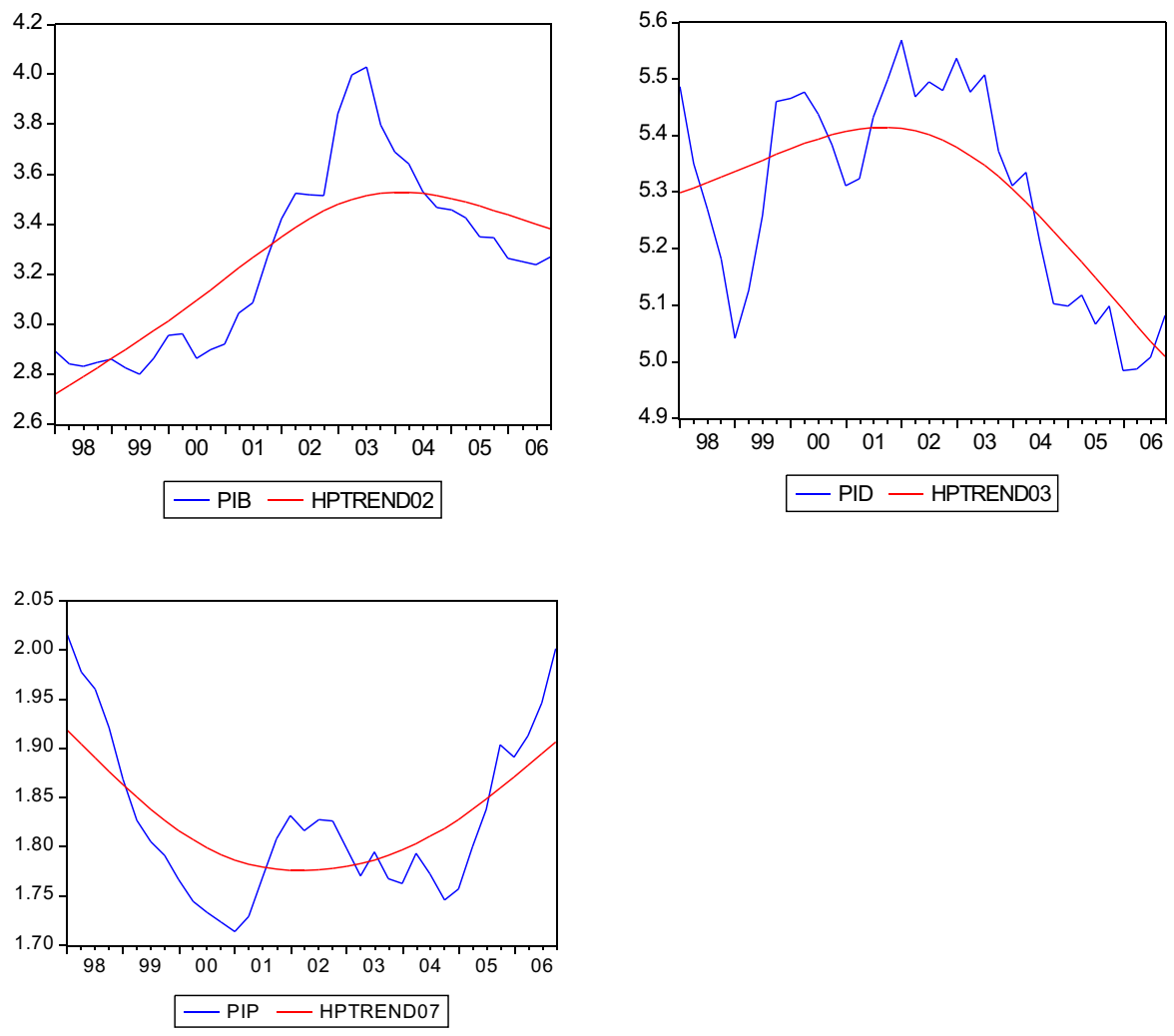

6 Households' income is represented by average wages (seasonally adjusted by Census X12 for further purposes). Housing prices are calculated on price index and average prices of year 2000 basis (published by the Czech Statistical Office - without new built real estates). The average size of house or flat equals average size in 2000 and is considered to be constant over whole period. The family houses price statistics is, however, not including the price of parcels (it is separated from houses) and it had to be added. Standard Hodrick-Prescott filter (with constant 1600) was used for trend modelling. 
Figure 1 illustrates an approximately 14\% increase in P/I ratio of flats over the period, however, $\mathrm{P} / \mathrm{I}$ for family houses was in 2006 below its initial value. Parcels are in 2004-2006 getting sharply above trend, reaching P/I vale of 1998 . Flats had a quite observable period of rapid increase and fall in 2003-2004, when the market faced a bubble caused by the accession of the Czech Republic to the EU and expected increase in real estate prices which did not happen.

Figure 2

Housing Real Price Growth (in \% on previous year)

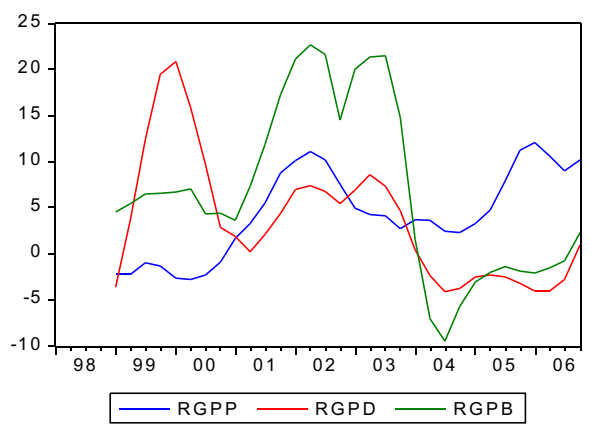

Housing real price growth and $\mathrm{P} / \mathrm{I}$ ratio is not bringing any clear evidence of housing price bubble. However the time series ends in 2006 and as the Financial Stability Report (Czech National Bank, 2008) shows, the housing prices increased rapidly in 2007. Taking into account such dynamics we cannot either prove or reject the bubble hypothesis on the analysis of $\mathrm{P} / \mathrm{I}$ ratio and real prices development only. It is possible that we will have a similar situation as in 2004 when at this time the rapid demand and prices growth are not determined by expectation of the EU entry but "market forward buying" caused by VAT increase in 2008. VAT influenced housing prices immediately (Jiřička, 2007) and therefore might have impact on housing prices development in the beginning (probably first half) of 2008 as well.

\section{Speculative Demand, Fundamental Analysis}

As stated above, the housing bubble generally appears when it is not possible to explain growth in prices on fundamental basis. The Czech Republic witnessed such unpredictable price boom (especially on market with flats) before the EU accession in 2004. In 2003, prices went up rapidly because households and investors anticipated fast growth in prices. However this situation did not happen and prices went back down as they went up after 2004. Sudden fall in prices was interconnected with mortgages which face stagnation in 2004. Figure 3 illustrates this situation. GHYPO stands for growth of volume of mortgages; $R G P$ is real growth in prices. 


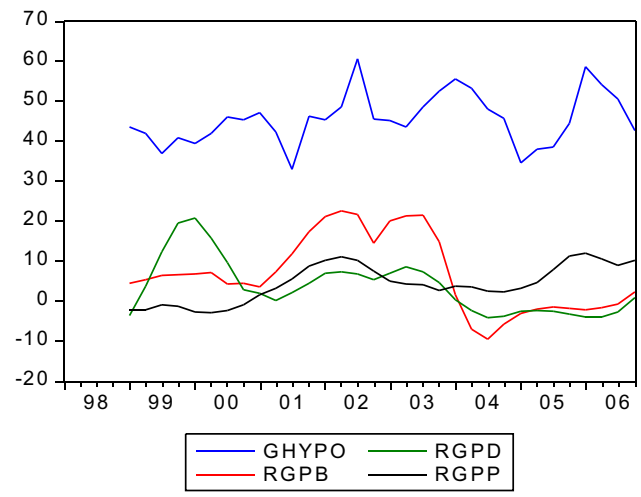

Figure 3 shows quite clearly that mortgage dynamics is somehow related to real prices development with a certain delay. It is a question whether causality is leading from mortgages to prices or vice versa. If high price dynamics was a reason for high volume of mortgages it would point at higher risk of price bubble existence and its subsequent impact on economy. ${ }^{7}$ Granger causality test was used for causality analysis with these results. ${ }^{8}$

Table 1

Granger Test of Causality

\begin{tabular}{|l|c|c|c|}
\hline Null Hypothesis: & Obs & F-Statistic & Probability \\
\hline RGPB does not Granger Cause GHYPO & 26 & 4.36066 & 0.01250 \\
\hline GHYPO does not Granger Cause RGPB & & 2.66736 & 0.06518 \\
\hline RGPD does not Granger Cause GHYPO & 26 & 0.50320 & 0.79534 \\
\hline GHYPO does not Granger Cause RGPD & & 3.07252 & 0.04245 \\
\hline RGPP does not Granger Cause GHYPO & 26 & 1.28794 & 0.32831 \\
\hline GHYPO does not Granger Cause RGPP & & 2.05170 & 0.13063 \\
\hline
\end{tabular}

Table 1 offers quite interesting results. Granger causality indicates possible dependence of flat mortgages on the flats price development and reverse dependence of mortgages on family houses. We may conclude that if there is a housing price bubble it would have a much substantial impact on flats than family houses. I addition the bubble bust is more probable on flats market than on family houses market because causality from prices to mortgages can indicate speculative motives.

7 The Financial Stability Report $(\mathrm{CNB}, 2008)$ is considering this causality to be very important but comes to different conclusion.

8 Granger causality test was undertaken with 6 period lag which offered the best results (the same causality direction was obtained when taking 4 lags - usually used for quarterly data analyses however, the F-statistic was a bit lower). 
Speculative demand is caused by non-fundamental factors especially by expectation of future rise in prices. There are of course a lot of factors which can be viewed as fundamental. For purpose of this paper there were chosen similar factors like in analysis dealing with housing price bubble in South Korea (Chung, Kim, 2004) with some modifications. ${ }^{9}$ Chosen variables are (quarterly data):

Flats prices $-P b$

Family houses prices $-P d$

Households income represented by average monthly wages (seasonally adjusted by

Census X12) - I_SA

Interest rate $-I R$ (represented by PRIBOR 1R)

Average construction cost $-P S$

Population in age 20-39-N

Housing construction - flats and family houses (seasonally adjusted by Census X12) $V_{d_{-}} S A, V_{B} S A$

Speculative part of the model is represented by adaptive expectations of price development (in other words there is a price lag). Chung and Kim (2004) used standard OLS despite non-stationarity of used time series. They are arguing that using stationary series will result in substantial loss of information. However a standard approach with stationary data is used here because (according to author himself) a threat of spurious regression is exceeding the loss of information problem.

After standard unit-root and cointegration tests of variables in logarithms ${ }^{10}$ it was necessary to make a first difference of logarithms to get stationary series (excluding construction costs which were initially taken in growth rates). However with regard to quite small data sample lags of variables were analysed individually by univariate regressions. Taking quarterly data into account 1-3 lags were chosen. Equation (1) and (2) show final models for flats prices and family houses prices with statistically significant variables only. ${ }^{11}$

$$
\Delta \ln (P b)=0,53 \Delta \ln \left(P b_{t-1}\right)+1,89 \Delta \ln \left(N_{t-3}\right)+0,55 \Delta \ln \left(I_{-} S A_{t-3}\right)
$$

9 The population group in age 20-39 was added as additional variable. It was calculated according to average yearly share of this group on total population (available on EUROSTAT) and quarterly population volume.

10 ADF test and Phillips-Peron test were made for unit roots. Johansen cointegration test rejected cointegration hypothesis for all variables.

$1110 \%$ significant level was chosen, however some variables reach even $5 \%$ and less - see $t$-statistics. Full regression output is in the Appendix. Univariate models are shown only for cases when there was no significant dependence. 
Model Representations - Flats $(P b)$

\begin{tabular}{|llll|}
\hline R-squared & 0.418199 & Mean dependent var & 0.020618 \\
Adjusted R-squared & 0.378075 & S.D. dependent var & 0.029699 \\
S.E. of regression & 0.023421 & Akaike info criterion & -4.581310 \\
Sum squared resid & 0.015908 & Schwarz criterion & -4.443897 \\
Log likelihood & 76.30096 & Durbin-Watson stat & 1.630074 \\
\hline
\end{tabular}

$$
\begin{gathered}
\Delta \ln (P d)=0,46 \Delta \ln \left(P d_{t-1}\right)-0,03 \Delta \ln \left(I R_{t-3}\right)+1,13 \Delta \ln \left(N_{t-1}\right)+0,32 \Delta \ln \left(\left(I_{-} S A_{t-2}\right)[2]\right. \\
(2,79)
\end{gathered}
$$

Table 3

Model Representations - Family Houses (Pd)

\begin{tabular}{|llll|}
\hline R-squared & 0.394189 & Mean dependent var & 0.015678 \\
Adjusted R-squared & 0.329280 & S.D. dependent var & 0.013429 \\
S.E. of regression & 0.010998 & Akaike info criterion & -6.065662 \\
Sum squared resid & 0.003387 & Schwarz criterion & -5.882445 \\
Log likelihood & 101.0506 & Durbin-Watson stat & 1.872429 \\
\hline
\end{tabular}

Fundamentals which could stand behind demand and determine "normal" price development were only income, population in age 20-39 and in case of family houses also the interest rate. Interest rate is not significant for case of flats which is quite interesting and it is corresponding with Granger causality results. Agents on the flat market followed more likely the price development itself than the interest rate. Surprisingly, construction and construction cost appear to be insignificant for housing price development in the Czech Republic. We may conclude that Czech housing market is strongly demand-oriented and supply side plays no substantial role so far.

The importance of particular significant variables or their contribution to overall housing price dynamics can be simply estimated by the following formula ${ }^{12}$

$$
S h_{i}=\frac{\sum_{t=1}^{T} b_{i} X_{i}}{\sum_{t=1}^{T} Y_{e s t}}
$$

where $S h$ is average share of factor on overall price dynamics, $b_{i} X_{i}$ stands for variable multiplied by corresponding regression coefficient, $Y_{e s t}$ stands for price development estimated by model. Table 4 shows the results (total sum is not precisely $100 \%$ because of approximations in regressors).

12 Similar in: Chung, H. S., Kim, J. H., 2004. 
Table 4

Factor Contribution to Overall Housing Price Dynamics

\begin{tabular}{|c|c|c|}
\hline Factor & $\begin{array}{l}\text { Contribution to Flat Prices } \\
\text { Development(\%) }\end{array}$ & $\begin{array}{l}\text { Contribution to Family } \\
\text { Houses Price } \\
\text { Development(\%) }\end{array}$ \\
\hline Speculative Demand & 48,5 & 44 \\
\hline Income & 42 & 34 \\
\hline Population (20-39) & 11 & 10 \\
\hline Interest Rate (PRIBOR 1R) & - & 11,5 \\
\hline
\end{tabular}

We may conclude that it is the price development itself - in other words the speculative demand - which is affecting the overall price development at most. The second most powerful factor is household's income. Besides these two factors also younger generations look for housing and it contributes to price development; however this contribution is in comparison to income and speculative motives quite weak. On the other hand, it must be stressed here that R2 is not very high (models explain around $40 \%$ of variation) for both cases - houses and flats - and therefore conclusions made here cannot be treated as fully reliable.

\section{Conclusion}

Housing price bubble analysis in the case of the Czech Republic is difficult for several reasons. Domestic market is still partly regulated and economy faced transformation in recent past which results in not very long time series of data available and sometimes even in lack of relevant and up-to-date data. Besides this fact, housing market is strongly regionally differenced (it is the same as in other countries) and currently the regional statistics is insufficient to make any deeper analysis in regions. These problems affect any housing market analysis that is undertaken and therefore also conclusions of this analysis cannot be treated as fully reliable.

The analysis revealed a possibility of speculative demand and housing price bubble on the Czech housing market. Basic indicators used for housing bubble identification like P/I ratio are not directly approving the bubble hypothesis, however their rapid development in the end of selected time series and in 2007 are somewhat alarming (see Financial Stability Report, Czech National Bank, 2008) even more with consideration to fast increasing gap between offered and realised prices in 2007.

Regression analysis revealed that Czech housing market is strongly demand-determined. The existence of speculative demand based on adaptive expectations was proved and identified as possibly the strongest determinant of overall price development. Such speculations enhanced by expected increase of VAT on housing after January 1, 2008 and possible "market forward buying" phenomena are probably standing behind rapid housing price acceleration in 2007. If we split the housing market between flats and family houses then flats are probably being exposed to more speculations than family houses and the bubble bust will have a stronger impact on them (this is especially the case of big cities like Prague).

With respect to undertaken analysis it could be concluded that housing prices will probably fall in near future. If the price development is similar to that of 2004 and the 
speculative demand is taken into account we may expect at first a slowdown in prices on the market in 2008 (especially in the first half when increased VAT is pushing prices up from expected stagnation) followed by succesive drop down in prices in second half of the year and following period.

\section{References}

Case, K. E., Schiller, R. J. (2003), "Is There a Bubble in the Housing Market?" Brookings Papers on Economic Activity 2003, No. 2, pp. 299-342.

ČNB (2008), Zpráva o finanční stabilitě / Financial Stability Report, 2008.

Chung, H. S., Kim, J. H. (2004), "Housing Speculation and Housing Price Bubble in Korea." Working Paper 04-06, KDI 2004.

Felsenthal, M. (2007), “Greenspan says: I Didn't See Subprime Storm Brewing." Reuters, 2007-09-14.

Financial Times 09-18, 2007: Greenspan Alert on US House Prices.

Harvard University, Joint Center for Housing Studies: The State of Nation's Housing, 2006.

Heij, Ch., Boer, P., Franses, P. H., Kloek, T., Dijk, H. K. (2004), Ecometric Methods with Application in Business and Economics. Oxford University Press, 2004.

Himmelberg, Ch., Mayer, Ch., Sinai,T. (2005), "Assessing High Housing Prices: Bubbles, Fundamentals and Misperceptions." Journal of Economic Perspectives 2005, Vol. 19, pp. 67-92.

Jiřička, J. (2007), Ceny rezidenčních nemovitostí. Knight Frank, 2007.

Lereah, D. (2005), Are You Missing the Real Estate Boom? Currency/Doubleday 2005.

Lereah, D. (2006), Why the Real Estate Boom Will Not Bust - And How Can You Profit from It. Currency/Doubleday, 2006.

Mayer, Ch., Quigley, J. M. (2003), "Is There a Bubble in the Housing Market? Comments and Discussion." Brookings Papers on Economic Activity 2003, No. 2, pp. 342-362.

Mills, T. C. (2003), "Modelling Trends and Cycles in Economic Time Series." Palgrave Texts in Econometrics, 2003.

Noord, P. (2006), “Are House Prices Nearing a Peak? A Probit Analysis for 17 OECD Countries." OECD Economic Department Working Paper No. 488, OECD, 2006.

Papadimitriou, D. B., Chilcote, E., Zezza, G. (2006), "Are Housing Prices, Household Debt and Growth Sustainable?" The Levy Economic Institute, 2006.

Stiglitz, J. E. (1990), "Symposium on Bubbles." Journal of Economic Perspectives. 1990, pp. 13-18.

\section{Web pages:}

www.czso.cz

www.cnb.cz

\section{APPENDIX}

Table 5

Dependence of Flats Price Development on Interest Rate

\begin{tabular}{|l|c|c|c|c|}
\hline Variable & Coefficient & Std. Error & t-Statistic & Prob. \\
\hline DLNIR & -0.060720 & 0.043863 & -1.384312 & 0.1776 \\
\hline DLNIR(-1) & -0.008648 & 0.044253 & -0.195418 & 0.8465 \\
\hline DLNIR(-2) & -0.028005 & 0.044817 & -0.624869 & 0.5373 \\
\hline DLNIR(-3) & -0.015474 & 0.041727 & -0.370827 & 0.7137 \\
\hline C & 0.015454 & 0.006231 & 2.480079 & 0.0197 \\
\hline
\end{tabular}


Table 6

Dependence of Flats Price Development on Flats Construction

\begin{tabular}{|l|c|c|c|c|}
\hline Variable & Coefficient & Std. Error & t-Statistic & Prob. \\
\hline DLNVB_SA & -0.007128 & 0.026797 & -0.266002 & 0.7923 \\
\hline DLNVB_SA(-1) & -0.024252 & 0.032551 & -0.745048 & 0.4627 \\
\hline DLNVB_SA(-2) & -0.032295 & 0.033718 & -0.957809 & 0.3467 \\
\hline DLNVB_SA(-3) & -0.029468 & 0.028792 & -1.023491 & 0.3152 \\
\hline C & 0.021505 & 0.005558 & 3.869293 & 0.0006 \\
\hline
\end{tabular}

Table 7

Dependence of Flats Price Development on Construction Costs

\begin{tabular}{|l|c|c|c|c|}
\hline Variable & Coefficient & Std. Error & t-Statistic & Prob. \\
\hline PS & 0.090273 & 1.837097 & 0.049139 & 0.9612 \\
\hline PS(-1) & -1.345608 & 1.894028 & -0.710448 & 0.4835 \\
\hline PS(-2) & -1.341052 & 1.870685 & -0.716877 & 0.4796 \\
\hline PS(-3) & 2.001425 & 1.622551 & 1.233505 & 0.2280 \\
\hline C & 0.024811 & 0.020419 & 1.215109 & 0.2348 \\
\hline
\end{tabular}

Table 8

Dependence of Family Houses Price Development on Construction Costs

\begin{tabular}{|l|c|c|c|c|}
\hline Variable & Coefficient & Std. Error & t-Statistic & Prob. \\
\hline PS & -0.971885 & 0.810975 & -1.198415 & 0.2412 \\
\hline PS(-1) & 0.507752 & 0.836107 & 0.607281 & 0.5487 \\
\hline PS(-2) & -0.086107 & 0.825803 & -0.104270 & 0.9177 \\
\hline PS(-3) & 0.850782 & 0.716265 & 1.187803 & 0.2453 \\
\hline C & 0.012671 & 0.009014 & 1.405736 & 0.1712 \\
\hline
\end{tabular}

Table 9

Dependence of Family Houses Price Development on Construction

\begin{tabular}{|l|c|c|c|c|}
\hline Variable & Coefficient & Std. Error & t-Statistic & Prob. \\
\hline DLNVD_SA & 0.056397 & 0.037587 & 1.500464 & 0.1451 \\
\hline DLNVD_SA(-1) & 0.005225 & 0.040390 & 0.129352 & 0.8980 \\
\hline DLNVD_SA(-2) & -0.032243 & 0.040674 & -0.792709 & 0.4349 \\
\hline DLNVD_SA(-3) & -0.029300 & 0.038927 & -0.752702 & 0.4581 \\
\hline C & 0.015609 & 0.002600 & 6.003906 & 0.0000 \\
\hline
\end{tabular}

